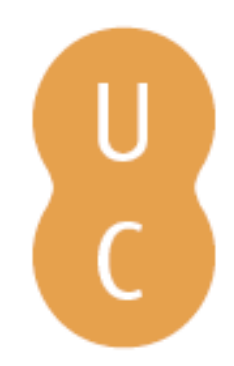

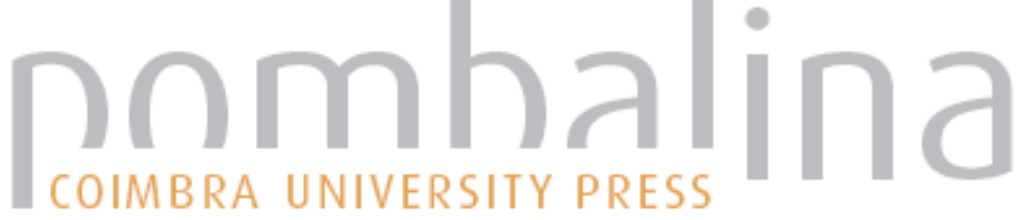

\section{The setting of Euripides' Andromache: an inquiry about Thetideion}

\author{
Autor(es): Mariani, Lucia \\ Publicado por: Imprensa da Universidade de Coimbra \\ URL \\ persistente: \\ URI:http://hdl.handle.net/10316.2/44722 \\ DOI: \\ DOI:https://doi.org/10.14195/978-989-26-1564-6_7
}

Accessed : $\quad$ 26-Apr-2023 13:16:26

A navegação consulta e descarregamento dos títulos inseridos nas Bibliotecas Digitais UC Digitalis, UC Pombalina e UC Impactum, pressupõem a aceitação plena e sem reservas dos Termos e Condições de Uso destas Bibliotecas Digitais, disponíveis em https://digitalis.uc.pt/pt-pt/termos.

Conforme exposto nos referidos Termos e Condições de Uso, o descarregamento de títulos de acesso restrito requer uma licença válida de autorização devendo o utilizador aceder ao(s) documento(s) a partir de um endereço de IP da instituição detentora da supramencionada licença.

Ao utilizador é apenas permitido o descarregamento para uso pessoal, pelo que o emprego do(s) título(s) descarregado(s) para outro fim, designadamente comercial, carece de autorização do respetivo autor ou editor da obra.

Na medida em que todas as obras da UC Digitalis se encontram protegidas pelo Código do Direito de Autor e Direitos Conexos e demais legislação aplicável, toda a cópia, parcial ou total, deste documento, nos casos em que é legalmente admitida, deverá conter ou fazer-se acompanhar por este aviso. 


\section{História Antiga:}

Relações

Interdisciplinares.

Fontes, Artes, Filosofia,

Política, Religião e Receção

\section{Carmen Soares, José Luís Brandão \& Pedro C. Carvalho (coords.)}




\title{
The setting of Euripides' AndRomaChe: AN INQUIRY ABOUT THETIDEION ${ }^{1}$
}

\author{
Lucia Mariani² (lucia.mariani@uniupo.it) \\ Università del Piemonte Orientale \\ Dipartimento di Studi Umanistici
}

\begin{abstract}
Aвstract - This paper shows that Euripides' Andromache is set in Thetideion, a toponym whose precise 'nature' has been much discussed. Euripides uses the toponym "Thetideion" in reference to the cult of Thetis near Pharsalus: the paper tries to deal with this matter by paying a special attention to the presence and the role of Thetideion in the Euripidean drama and to other primary and secondary sources. The analysis of the sources leads to the conclusion that Thetideion was the name given by the Thessalian people both to a sanctuary to Thetis and to a little territory nearby Pharsalus. They chose that name in memory of the wedding between Peleus and Thetis.
\end{abstract}

KEywords - Euripides; Andromache; Thetideion; setting; polis; sanctuary

Euripides' Andromache begins with a suppliant scene where Andromache goes to Thetis' shrine ${ }^{3}$ and asks her protection ${ }^{4}$. This beginning is common to the prologues of other Euripidean tragedies: a supplication ${ }^{5}$ is made to the altar of Zeus agoraios in the Heraclides; to the altar of Zeus in the Heracles and to the

${ }^{1}$ I would like to thank Professor Luigi Battezzato and Professor Michael Lloyd for their helpful comments. For the defects that remain, the full responsibility is mine.

${ }^{2} \mathrm{PhD}$ student in "Linguaggi, storia e istituzioni".

3 Thetis was one of the Nereids, daughter of Nereus and Doris (e.g. Hes. Th. 240-244; Hom. Il. 1. 358; 18. 36; Pind. P. 3. 92; Apollod. 1. 11; for a general summary of the literary sources about the goddess see RE s.v. Thetis, coll. 218-221). In the Iliad, Thetis is a nurthering mother (kourotrophos) and protective deity (Slatkin 1991: 7), but she is also quite human (e.g. Griffin 1980: 190-191). The nurturing function of the goddess, symbolized by the image of the vegetal growth, as e.g. at Hom., Il. 18. 437-438, concerns the relationship between the goddess herself and the kouros (Slatkin 1991: 41, n. 26; Merkelbach 1971: 80; Vidal-Naquet 1968: 947-949). Thetis's kourotrophic function was discussed and compared with the one of Cheiron by E. Aston (2009).

${ }^{4}$ According to Euripides, Thetis is the Nereid par excellence: he often underlines her leading role among her sisters and her strong relationship with the sea (Jouan 1966). This strong relationship is evident in her epithet $\theta \alpha \lambda \alpha \sigma \sigma i \alpha$, given by Euripides exclusively to her:


Achillem; Kannicht ad loc.); almost analogous to this clause and always referred to Achilles,

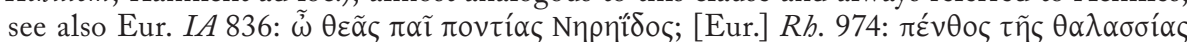
$\theta \varepsilon o \tilde{u}$ [scil. Thetidos]. Liapis 2012 ad loc. cites the parody of this verse made by Aristophanes at Ran. 840.

${ }^{5}$ Among the recent works about the hiketeia, for a complete introduction see Naiden 2006. 
altar of Demeter in the Supplices. Moreover, the interest of Euripides for local cults is evident in many tragedies ${ }^{6}$ : just to mention two of the most famous ones, the cult at Brauron is at the centre of the Iphigeneia in Tauris; the cult in the temple of Hera at Corinth is explained in the whole $\mathrm{Medea}^{7}$. The reliability of Euripides for the description of cults and aitia has been much discussed: on the one hand, there are some people who are completely sceptical about the content of Euripidean texts and think that the poet invented all his descriptions with no link with real cults ${ }^{8}$. On the other hand, this drastic position has been contrasted by some critics who think that the Euripidean descriptions can be trustworthy and are rooted in his contemporary reality ${ }^{9}$. This second point of view seems more balanced and shareable: the amount of lost materials and witnesses about the ritual practices is so huge that, even in the cases in which Euripides is our only source, it is wrong to assume that he invented all. On the contrary, Euripides created his own works and descriptions by following a principle of verisimilitude, i.e. by inventing and probably adding elements and details, but at the same time by referring to real cults and practices ${ }^{10}$.

In the case of Andromache, it is difficult to state whether Euripides referred to a real cult of Thetis or not: Euripides' mention of a sign of Thetis' cult is made just as an essential part of the setting of the play and not as a 'well-structured' cult. In the developing of this tragedy, it is indeed plain that Euripides is not interested in the cult of Thetis per se: he does not give any details about the cultic practices or the possible presence of priestesses ${ }^{11}$. On the contrary, it seems that

\footnotetext{
${ }^{6}$ For an overview about the relationship between Euripides and ancient Greek religion and cults see the ch. III of Sourvinou-Inwood 2003.

${ }^{7}$ The description of local cults is also present in Electra, Iphigeneia in Tauris, Medea, Helen, Erechtheus, Cretans (Battezzato 2016: 4, with specific references).

${ }^{8}$ Emblematic in this sense is Scullion 1999-2000.

${ }^{9}$ Dunn 2000; Seaford 2009.

${ }^{10}$ Battezzato 2016: 12.

${ }^{11}$ The form and content of Thetis' cult are unclear: in his notae on Apollod. 3. 13. 5, C. G.

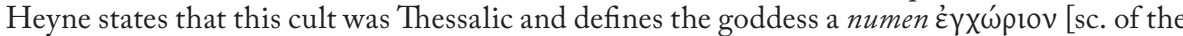
country, rustic], quod Achillis celebritate et ipsum celebrationem maiorem accepit. In the ancient Greek world, in contrast with her key role in the mythography, the cult of Thetis was not well known: in addition to the single mention of the temple to Thetis in Laconia (Paus. 3. 14. 4-6, on which see Larson 2007: 69), Pausanias describes some other altars and temene on the seashores dedicated to the Nereids with Achilles (Paus. 2. 1. 8). Moreover, Herodotus records that some ritual practices to Thetis were celebrated at Cape Sepias where the Persians, having suffered heavy damage in a storm, sacrificed to her and the Nereids as local deities (Hdt. 7. 191. 2). It is suggestive to think about the fact that the cult in inland Pharsalus could resonate with the tradition - first attested in Hdt. 7.129 - that Thessaly was once a sea (Mili 2015: 42; 176, n. 79). It is also possible that the fact that Thetis' cult, unlike those of the Olympian gods, remained geographically circumscribed, was linked with Thetis' status in the Homeric epic: "it may be the case that Thetis's stature in a local context is a factor in the Iliad's reticence or indirectness of reference with respect to her power and prestige" (Slatkin 1991: 81).
} 
the setting of the play and the temple dedicated to the deity are a kind of pretext for the building of the dynamics of the plot, a perfect tile of the whole mosaic of the play. The altar and statue of the goddess have a key scenic role ${ }^{12}$ and the supplication to Thetis a specific meaning: at the end of the tragedy, Thetis will confirm her protective function by making her entrance ex machina and solving the complex plot by rescuing Andromache and Peleus ${ }^{13}$.

The reasons of her intervention are immediately stated: in memory of their wedding ${ }^{14}$, Thetis has come to rescue Andromache and Peleus; in memory of this wedding, she promises her husband immortality ${ }^{15}$. Remarkably, at the beginning of the play Andromache uses almost the same expression of Thetis ( $\chi \alpha$ óp

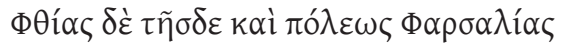

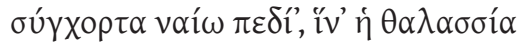

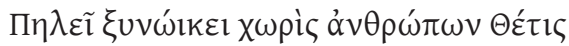

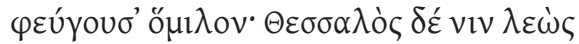

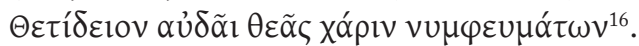
I live in the plains that border on this Phthia and the city of Pharsalus, plains where the goddess Thetis, far from the haunts of men and fleeing their com- pany, dwelt as wife of Peleus; the Thessalian people call this place Thetideion, in memory of the goddess' marriage ${ }^{17}$.

${ }^{12}$ Thetis' sanctuary is the fulcrum of the play's action and was probably situated at the middle of the orchestra (Kuntz 1993: 64-76; Rehm 1988: 303; 2002: 41; Mirto 2012: 46).

${ }_{13}$ The intervention of Thetis creates "a balanced close to a disrupted and unsettling sequence of events. The broken and mournful Peleus, a former rescuer, is rescued himself. In his personal vicissitudes from rescuer to tragic victim to survivor, Peleus articulates a key theme (of virtue rewarded) and illuminates an important aspect of the play's fluctuating and disjunctive structure" (Allan 2000: 81). Moreover, it has been rightly noted that just as in Aeschylus' Eumenides Athena notices that Orestes is sit next to her simulacrum inside the temple (409), so in the Andromache Thetis' final appearance creates a sort of mirror effect, since the goddess substitutes the statue with her own presence (Mirto 2012: 64).

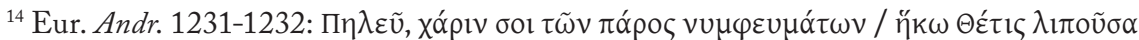

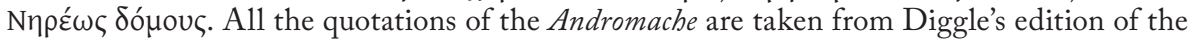
text (1984). The wedding between Peleus and Thetis, one of the most famous of the whole classical mythology, was told by various traditions (Jouan 1966: $68 \mathrm{ff} .$, with rich bibliography) and is the topic of many representations, both literary (e.g. Pind. I. 8; Catul. 64) and iconographic (LIMC VIII s.v. Thetis: 7-9; Gantz 1993: 229-231).

${ }^{15}$ However, it has been underlined that "the future is not what Peleus had hoped for. The gods have promised that neither his race nor that of the Trojans will die out, but their survivors will live on in an obscure place and with a different name; it is an outcome that is tinged with regret for a more glorious past and hopes that will never be fulfilled" (Lefkowitz 2016: 152).

${ }^{16}$ Eur. Andr. 16-20.

${ }^{17}$ All the translations of the ancient Greek texts here quoted are mine. 
This section presents several problems of interpretation that concern and at the same time allow us to understand the 'nature' of Thetideion ${ }^{18}$. In this sense, lines 19-20 are a key passage because of two elements: the pronoun $\operatorname{nin}^{19}$, which is referred to the synchorta pedia, and Thetideion as the name that the people gave to the same pedia. At line 20, indeed, Andromache mentions clearly the place where the drama is set: Thetideion, name given by the Thessalian people to the synchorta pedia where she lives, in memory of the wedding between Peleus and Thetis. However, this is the only mention of Thetideion throughout the whole tragedy: elsewhere, the characters who come into the scene do not refer to it, but to Phthia ${ }^{20}$. Hence, there seems to be an apparent short-circuit between Thetideion, Phthia and Pharsalus: in order to understand this better, it is necessary to go back to lines $16-17$, and in particular to the meaning of the word synchortos ${ }^{21}$.

If the two genitives at line 16 depended on pedia ${ }^{22}$, the translation should be: "I dwell on the neighboring plains of this Phthia and the city of Pharsalus", plains with pastures adjoining, i.e. Thetideion would be enclosed between Phthia itself and Pharsalus. Probably, this was the interpretation of the scholiast: $\mu \varepsilon \tau \alpha \xi \dot{v} \delta \dot{\varepsilon}$

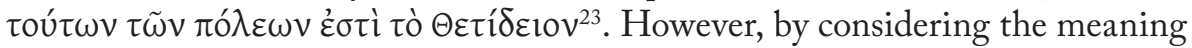
and the absence of 'absolute' uses of synchortos, i.e. of the adjective alone, without

${ }^{18}$ The name Thetideion recalls the ones with the suffix -10 (nom. $-10-v$, neut.): $\Delta$ lovv́ $\sigma$ iov

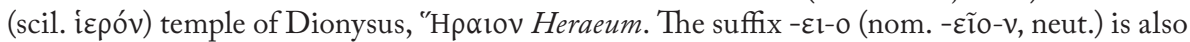

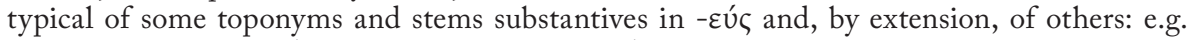

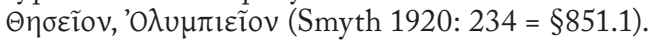

${ }^{19} \mathrm{Nin}$, third person accusative pronoun, is the doric equivalent to the ionic and epic form min (LSJ s.v.) and the attic auton, auten. In tragedy, nin is used both as a masculine and feminine form, both singular and plural, more rarely as a neuter plural accusative (KühnerBlass 1890-1892: I 592; Johansen-Whittle 1980 ad Aesch. Suppl. 729; Stockert 1992 ad Eur. IA 327, 552; Battezzato 2018 ad Eur. Hec. 264).

20 The female chorus claims to come from Phthia (119); Andromache and Orestes, with the same words, say they have come to Phthia (402-403; 886-887), as well as Menelaus (730); Peleus claims to rule over a throng of cavalry and many oplites in Phthia (760) and Menelaus makes reference to Neoptolemus' reign as ghe Phtiotis (664); in a similar way, Hermione asks Orestes to drive her away from the land of Phthia (922; 925). In addition to this, the Andromache's hypothesis attributed to Aristophanes of Byzantium and some modern translations and commentaries of the Euripidean text claim that the setting of the tragedy is in Phthia (e.g. Stevens 1971; Scodel 2012: 13).

${ }^{21}$ Synchortos is a possessive compound word, attested from Aeschylus (Suppl. 5) and used by Euripides only in three cases (Andr. 17; fr. 179, 3; HF 371); its meaning, as the scholiast commented (schol. in Eur. Andr. 17), is the same as such words as plesiochora, gheitona, synora, i.e. 'bordering'. The ancient lexicographers, e.g. in the context of the definition of the meaning of chortaios, which conveys the concept of border and enclosure, quote this line together with Hom. Il. 11. 774 (aules en chorto - for all these quotations see Kannicht ad Eur. fr. 179).

${ }^{22}$ Stevens 1971 ad loc.

${ }^{23}$ Schol. in Eur. Andr. 17, ed. Schwartz 1891. 
other cases or complements, its grammatical role and its position in the context of lines 16-17 would be much more difficult to explain ${ }^{24}$. On the contrary, if the two genitives at line 16 depended on synchortos, the translation should be: "I live in the plains that border on this Phthia and the city of Pharsalus"; hence, there would not be an intersection between the places, but they would be only adjoining. This hypothesis has its own rationale, especially for the existence of a parallel in another Euripidean tragedy ${ }^{25}$ and for the fact that the synonyms of synchortos are construed mainly with the dative, but also with the genitive ${ }^{26}$.

If the synchorta pedia - i.e. Thetideion ${ }^{27}$ - are the setting of the play, it is important to underline that Phthia should at least be - as the scholium wrote - a metropolis; in other terms, the problem that Euripides is here touching upon is the ambiguity and uncertainty upon whether Phthia was a city or a region ${ }^{28}$ : in this context - and in general in the whole Andromache - he leaves it open. Nonetheless, by taking Thetideion into account as the play's setting and the fact that in the whole tragedy the characters mention Phthia and the land of Phthia,

${ }^{24}$ In addition to this, there is the question of the deictic tesde at line 16: Euripides uses the deictics also in other prologues in order to describe the skené (e.g. Med. 10; Hipp. 12). In

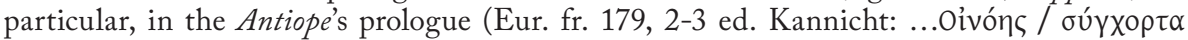


that the same deictic is linked with the adjective synchortos. By considering these elements Phthia could therefore be the setting of the Andromache; nonetheless, it is also necessary to remember that at lines 19-20 Andromache claims to live in the synchorta pedia, i.e. Thetideion.

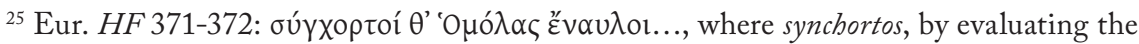
context, the meaning of the term itself and the absence of other cases where it is used in an 'absolute' way, seems to be construed with the genitive Omolas (see Kovacs 1998 ad loc.: "the settlements that neighbor Mount Homole”; contra Wilamowitz-Moellendorff 1969 ad loc.: "Homolegründe, saget es, Nachbarn").

${ }^{26}$ See e.g. omoros with gen.: Th. 2. 85. 5; 2. 99. 3; X. Cyr. 4. 2. 1; Paus. 1. 44. 4; 2. 12. 3, 2. 34. 4; the use of the genitive is also frequent in late antiquity prose.

${ }^{27}$ See RE s.v. VI A: 206: “in T. spielt die Andromache des Euripides”; Lloyd 2005: 10; Kovacs 1995; Allan 2000: 49.

${ }^{28}$ The dramatic situation set by Euripides is "a learned compromise, reflecting debate about where Achilles came from" (Lloyd 2005: 10): the most probable and agreed hypothesis is the one that considers Phthia as a region of the Spercheios valley, in south-eastern Thessaly (Hom. Il. 23. 141-142) and the area to the north of the Malian Gulf looking across toward Euboea (Mackie 2011). The uncertainty upon Phthia as a city or a region has its roots in the Iliad, where it is mentioned as Achille's homeland and defined sometimes as a region (1. $154-157 ; 9.395 ; 9.483)$, sometimes as a city $(9.253=9.439=11.766 ; 16.13 ; 19.322 \mathrm{ff})$. In addition to this, the Pelides claims to come also from Hellas (2.683-864; 9. 395; see also Od. 11. 495 ff., 16. 595 ff. for Hellas; 1. 155 and 9. 363 for Phthia) and only in Il. 16. 595 is Hellas mentioned without Phthia; on the contrary, Phthia appears often without Hellas (Fowler 2011: 871). In analogy with the history of the use of the toponym 'Hellas', which was at the beginning a place in middle-northern Greece, then the toponym for the whole Greek territory (Fowler 1998; Hall 2002), it is probable that also Phthia was a region (Vissner ad Hom. Il. 2. 683 Latacz series; Vissner 1997: 653); as in the cases of Pilos and Elis, the kingdom of Peleus and its main city would have been called with the same name as the region, Phthia (Vissner 1997: 665). 
it could be reasonably supposed that Euripides considered it a region more than a city.

Thetideion occurs only at line 20 and is never mentioned again: the other references to the cult of Thetis in the play are made to her anaktoron (46) and agalma $(246,565)$.

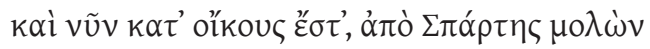

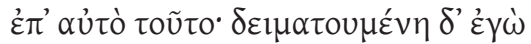



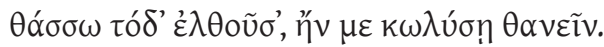

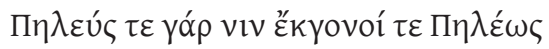

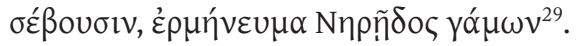

And now he [sc. Menelaus] is in the house and has come from Sparta for this purpose. I in fear have come and taken my seat at this shrine of Thesis, which is next to the house, in order not to be killed. Peleus and his descendants worship this place as the monument to his wedding with the Nereid.

At lines 43-44 Andromache claims that she's just come to Thetis' shrine but is the Thetideion only this? This would be contradictory with the already quoted lines 19-20: Thetideion is the name given by the Thessalian people to the synchorta pedia where Andromache herself lives. Nonetheless, by commenting line 46 and the naming of the anaktoron as ermeneuma, the scholiast to the $A n$ dromache questions the definition of the 'nature' of Thetideion:

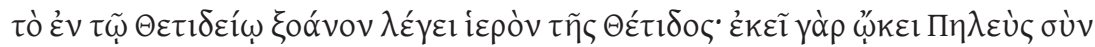

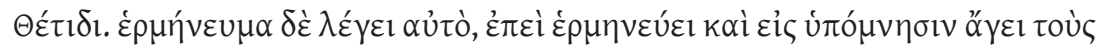

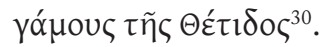

He refers to the sacred image of Thetis in the Thetideion; Peleus lives there with Thetis. He defines it a monument, because it symbolizes and reminds (people) of the wedding of Thetis.

Hence, from this quotation it could be understood that Thetideion was a temple with a sacred image of Thetis; the same deduction is possible from the scholium on

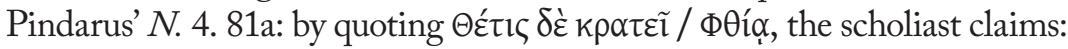

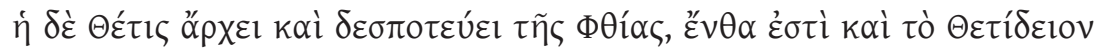

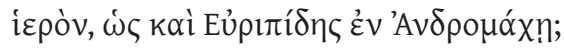

Thetis reigns upon Phthia, where there is also the Thetideion temple, as Euripides wrote in the Andromache.

\footnotetext{
${ }^{29}$ Eur. Andr. 41-46.

${ }^{30}$ Schol. in Eur. Andr. 46. 3.
} 
Nonetheless, at line 43 Andromache defines the shrine of Thetis domon paroikon, i.e. dwelling beside the house, that is - as Andromache herself said at line 24 - Neoptolemus' royal palace ${ }^{31}$ : Thetideion should therefore be a small place, with the royal palace, Thetis' temple and, from what Euripides tells us, surely not very populated ${ }^{32}$. Furthermore, in the parodos the chorus suggests Andromache to give up and obey Hermione by leaving the sanctuary of Thetis:

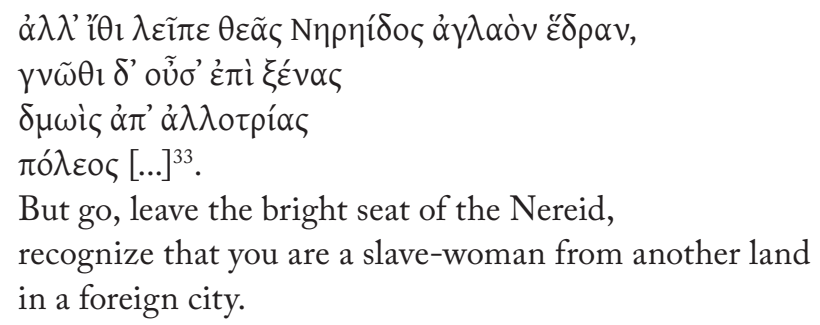

Andromache is the slave of a foreign polis: the chorus does not specify which polis is referring to, but, if the royal house was in Thetideion - as it seems from the above quoted Andr. 16-20 - we should suppose that the chorus is referring to Thetideion. Similarly, a little bit further, in her speech to Andromache Hermione underlines that the Trojan princess is not more defended by Hector or Priam: she is in a Greek polis ${ }^{34}$.

Thus, the ambiguity between Thetideion as a polis or a sanctuary stems in a certain way from the Euripidean text itself $\mathrm{f}^{35}$. Additionally, the idea of Thetideion as something more than a temple - more precisely, of Thetideion as a polis - is present in many other witnesses ${ }^{36}$. In the same scholium to Pindarus' fourth

${ }^{31}$ The use of the word domos to designate a royal house is common and very frequent in Euripides: only in Andromache, it defines Neoptolemus' palace at 43, 73, 344, 495, 876, 897, 959, 1055, 1057 (domon); 156, 926 (domous); 549 (domos); 24, 347, 932, 934 (domois); 924 (domoi); more generally the domos as the proper place of origin at 130, 309, 568, 602, 612, 674, 767, 784, 949, 1221, 1232, 1257, 1261.

The adjective paroikos is instead used by Euripides only in two other cases (IA 276; Hyp. fr. 18. 2), with the same meaning of Andr. 43.

${ }^{32}$ Eur. Andr. 18-19. By making a similar point to Lloyd (2005: ad Eur. Andr. 18-19), S. Mirto underlines that the fact that Peleus and Thetis chose to live in an isolated place mirrors the impossibility for them to integrate themselves in a civic community and the impossibility to link together the human and the divine world (Mirto 2012: 51).

${ }^{33}$ Eur. Andr. 135-138.

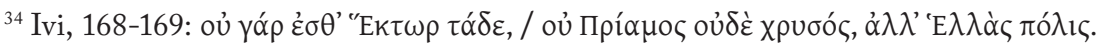

${ }^{35}$ As Professor M. Lloyd suggested to me, the ambiguity could stem also from different understanding of the world 'polis'. As a matter of fact, this world can be used in literature quite broadly, e.g. in the sense of country (Sommerstein 1990 ad Ar. Lys. 32, with references).

${ }^{36}$ Pherecyd. FGrH 3 F 1; Phylarch. FGrH 81 F 81; schol. in Pind. N. 4. 81b, quoting 
Nemean we read this quotation of Pherecydes ${ }^{37}$ about Thetideion:

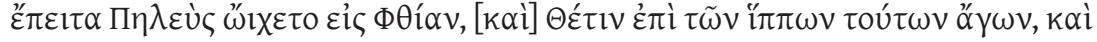

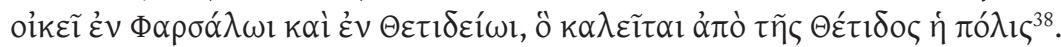 Then Peleus went to Phthia by carrying Thetis on these horses, and he lives in Pharsalus and Thetideion, that is called so from Thetis and is a polis.

The same quotation of Pherecydes is summed up in the scholium on Eur. Andr. 17, which, after having quoted lines 16-20, comments:



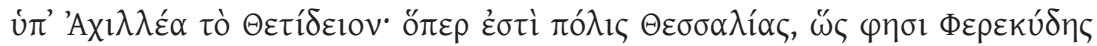



Phylarchus; schol. in Eur. Andr. 17. 7; Str. 9. 5. 6; Hdn. Gr., De pros. Cath. 3.1: 375. 1; Steph. Byz. 521. 8, quoting Hellanicus FGrH 4 F 136.

It is worth pointing out that, among the examples that define Thetideion as "polis", Hansen and Nielsen (2000: 148, n. 21) quote Eur. Andr. 16; they identify the "poleos Pharsalias" with Thetideion and refer to Stevens' commentary, who actually does not support this interpretation (1971: ad loc.). This identification would be a nonsense for many reasons: if the polis Pharsalia was Thetideion, the synchorta pedia where Andromache lives would be yet a third place, not elsewhere specified or described. Moreover, in this interpretation the adverb of place hina at line 17 should be linked with poleos Pharsalias, but this would be quite ungrammatical and illogical. Pharsalias is an adjective of the city name 'Pharsalus', not only in many other cases and authors (e.g. Plu. Pomp. 68. 1, 71. 1; Comp. Ages. et Pomp. 4. 4; Th. 8. 92. 8; X. HG 4. 3. 8, 6. 1. 2; Ages. 2. 4), but also in the same Andromache, e.g. at line 22, as the scholium clearly explains. Last but not least, if Thetideion was a polis, we should suppose that Euripides is not here thinking about a 'classical' meaning of the term, because - as it has just been showed - at lines 18-19 he states that Thetis lived there far from other human beings.

${ }^{37}$ Pherecydes of Athens wrote many works on mythical and genealogical topics, mostly around 465 B.C. (Fowler 2000: 272; Thomas 1989: 161-178, Dolcetti 2004: 12 ff.).

${ }^{38}$ Pherecyd. FGrH 3 F 1a - schol. in Pind. N. 4. 81c ed. Drachmann 1997. It is worth noting that Schwartz's conjecture oikei (quoted in the Jacoby's apparatus at FGrH 3 F 1a) seems more appropriate to the context.

${ }^{39}$ Schol. in Eur. Andr. 17 = Pherecyd. FGrH 3 F 1. This fragment and the scholium on Pind. N. 4. 81c were often quoted as proof for a possible overlapping and identification between Phthia and Pharsalus (Bernert: RE s.v. XX, 1, col. 950; Hope Simpson-Lazenby 1970; Vissner 1997: 655, n. 31), but it is clear that they do not deal with Pharsalus like the later Phthia. As a matter of fact, in his commentary, Jacoby states that Phthia was a district whose main city was Pharsalus, and not that here Pherecydes is superimposing or identifying them (p. 388).

In support of the identification between Phthia and Pharsalus, Bernert (RE s.v. XX, 1, col. 950) quotes also Eur. Andr. 16 ff., but this cannot be deduced from Euripides' text (see also Vissner on Hom. Il. 2. 683-684, Latacz's series: by quoting Eur. Andr. 16 and Str. 9. 5. 6, the author distinguishes between Phthia and Pharsalus, stating that, if Phthia was a district, Pharsalus was its main city). In any case, Euripides seems to be aware of the ambiguity and overlapping of these places, as implicitly proved by the $I A$, where Achilles comes both from Phthia $(103,237,713,954)$ and from the ghe Pharsalis (812); nonetheless, it is the ghe Pharsalis that in all likelihood was included in the region/reign of Phthia itself (Stockert 1992 ad loc.). 
This he took from the history. Peleus lived there together with her, and under the reign of Achilles there was the Thetideion, that is a polis of Thessaly, as Pherecydes and the Suidas state.

Pherecydes seems therefore to consider Thetideion a polis: nonetheless, the position of the word in the scholium on Pindarus is quite strange and makes us suppose that it is a later addition, perhaps influenced also by the above quotation of Phylarchus that defines Thetideion a polis ${ }^{40}$. As Professor Battezzato suggested to me, from a syntactic point of view, it should be considered that the masculine feminine apposition is possible, but in this context it oddly adds a subject with the article to an already expressed subject ${ }^{41}$. In this sense, it is also worth noticing that the manuscript $\mathrm{P}$ has another version of the scholium on Pindarus'

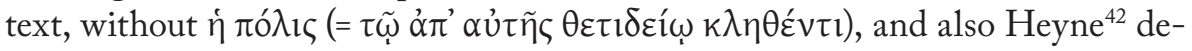
leted it. Furthermore, in his commentary to FGrH 602 F 6, Jacoby wrote that

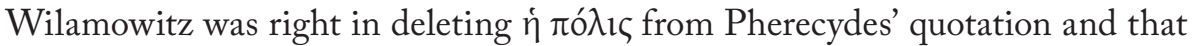
neither this quotation, nor Euripides (Andr. 43), Polybius (18. 20. 6) and Strabo $(9.5 .6)$ can lead to designate the temple Thetideion a polis or a land ${ }^{43}$. The overall impression is therefore that the scholiasts and ancient commentators did not know Thetideion and, assuming it to be a place name, defined it as a polis generically and by a sort of analogy $y^{44}$.

However this may be, and even if Pherecydes really mentioned Thetideion as polis, it has been underlined that this definition should not be understood in the same political sense as the other poleis of the classical period ${ }^{45}$, but "in a purely mythological context" ${ }^{\prime \prime 6}$. In other terms, Thetideion was "probably simply a locality in Pharsalian territory with a sanctuary of Thetis, and Pherekydes' interest centres on its name, not its status" ${ }^{\prime 7}$. There are indeed other cases where

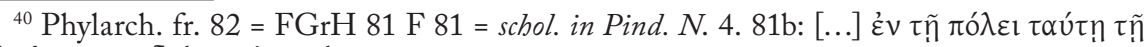

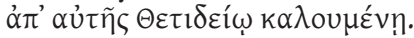

${ }^{41}$ On this 'weird' construction see also infra n. 49.

${ }^{42}$ Ad Apollod. 3. 13. 5, quoted in the apparatus of Drachmann 1997.

${ }^{43}$ On the last two sources see infra p. 159-160.

${ }^{44}$ The interest in the name Thetideion more than in its status as a polis is clear also in the Hellanicus' fr. 136 - quoted by Stephanus of Byzantium (521. 8) - who stated that the correct name was not Thestideion, but Thetideion, without the sigma: for a discussion of this fragment see Battezzato 2016: 10. The discussed Hellanicus is identified with the logographer Hellanicus of Lesbos of the V cent. B.C. (Fowler 2000: 146): for a different datation and the identification of this author with a grammarian contemporary to Aristarchus see Montanari 1988: 45-55.

${ }^{45}$ The question of what constitutes a polis is quite controversial: since the beginning of the 90s, the Copenaghen Polis Centre devoted to it many works. For an introduction to the problem see Hansen 2006.

${ }^{46}$ Decourt et al. 2004: 703.

${ }^{47}$ Hansen-Nielsen 2000: 148. According to Fowler, Thetideion is "the strongest case in 
Pherecydes used the term polis "in a retrospective mythological way with no intention of or interest in contemporary site-classification" ${ }^{\text {"8: }}$ as for Thetideion, Pherecydes mentions Sypilos, Ereuthalie, Lerne, Oresteion and Oitylos in order to give some mythological explanations about their names and stories, and defines them poleis in all cases ${ }^{49}$. Let us focus on the case of Oresteion:

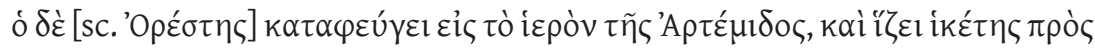

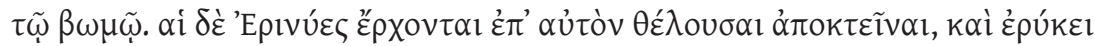

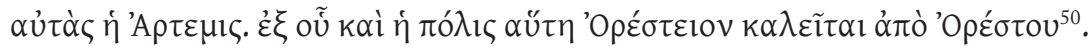
Orestes takes refuge in the temple of Artemis, and seats as a suppliant at the altar. The Erinyes arrive with the intention to kill him, and Artemis blocks them. As a consequence, the polis itself is called Oresteion after Orestes.

The fragment of Pherecydes is about Orestes' flight and pursuit by the Erinyes: the mythographer mentions Oresteion as the refuge of Orestes, by referring to a popular etymology ${ }^{51}$. The case of Oresteion is very interesting because Euripides - in a very similar way to Pherecydes - defines it a polis in a passage of the Electra where he explains that the hero will found a city in the Arcadian territory that will be called after his name ${ }^{52}$ :





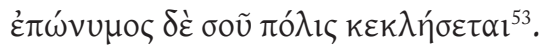

our corpus for the mythographers' assigning polis-status to a mythological location honoris causa" (2013: 446). Decourt states that it was an "agglomeration thessalienne" (1990: 206) of a certain importance, since there was the palace of Neoptolemus, thus implicitly agreeing about the fact that the skené of the Andromache is Thetideion as temple plus palace, and not Phthia.

${ }^{48}$ Hansen-Nielsen 2000: 148; on their work and this 'mythological use' see Figueira 2008: 325; 2009: 265.

${ }^{49}$ For the precise quotations and references see Hansen-Nielsen 2000: 148-149. It is worth pointing out that in all these quotations the word polis never appears at the end of a proposition. Moreover, in the whole corpus of Pherecydes there is never a similar use of an apposition linked with a relative pronoun, as in the above quoted and discussed scholium on Pindarus.

${ }^{50}$ Pherecyd. FGrH 3 F 135A.

${ }^{51}$ Fowler 2013: 441. There was also another explanation of the name Oresteion, according to which its eponym was Orestheus son of Lykaon of Parrhasia (Paus. 8. 3. 1-2).

${ }^{52}$ Oresteion is called 'polis' also in Paus. 8. 27. 3; 8. 44. 2; schol. in Eur. Or. 1645-1646; Steph. Byz. 494. 23. The small town was situated in the upper Alpheus valley on the road from Sparta to Tegea, not far from Parrhasia (Willink 1986 ad Eur. Or. 1645-1647; Cropp 2013 ad Eur. El. 1273-1275).

${ }^{53}$ Eur. El. 1273-1275. In the Electra Euripides chose to not follow the most famous versions of Orestes' story, according to which he established himself at Argos/Mycenae (or Sparta) and was succeed by his son Tisamenus until the return of the Heracleidae. 
It is necessary that you found an Arcadian city besides the stream of Alpheus near the sacred enclosure to Lycean Apollo: the city will be called after your name.

The examples of the definition in Pherecydes of Oresteion and Thetideion as poleis thus enlighten the mentions of these places by Euripides: in the case of Oresteion, Euripides defines it a polis, but it seems that in mentioning it his focus is not on the 'political' meaning of the word, but on its mythological content ${ }^{54}$. Similarly, it seems clear that in the Andromache he was not interested in giving details about Thetideion, but used it only as a tool for the setting and developing of the plot ${ }^{55}$.

In addition to this, it is important to point out that the status of polis of Thetideion does not stem from the other ancient sources that quote it: Thetideion is mentioned twice by Polybius during the description of the battles of Cynoscephalae of 364 B.C. and 197 B.C. ${ }^{56}$, but the historian does not specify whether it is a polis or a sanctuary (from the context it seems much more probable to be the second one). Polybius defines it to Thetideion tes Pharsalias, by thus confirming that it was a real place in Thessaly, in the Pharsalian territory ${ }^{57}$. Thetideion was situated in Thessaly also by Strabo, who does not specify whether it was a polis or a sanctuary, but claims only that it was located next to both Pharsalus, the Old and the New one ${ }^{58}$.

Nonetheless, the exact site of Thetideion is not agreed upon ${ }^{59}$ : three hypotheses have been formulated ${ }^{60}$. The most plausible is that of N. I. Giannopoulos,

${ }^{54}$ This of course does not imply that Euripides did not deal with the contemporary polis, whose Athens was in a certain way the model (see e.g. Lloyd 2006).

55 The history of the cohabitation of Peleus and Thetis has for the people the mere function of an aition for the toponym of Thetideion (Mirto 2012: 51).

${ }^{56}$ Plut. Pel. 32; Plb. 18. 20. 2-8.

${ }^{57}$ See Walbank on Plb. 18. 20. 2-8; Pritchett 1969. The specification tes Pharsalias could also mean that Polybius was probably aware of other places called Thetideion.





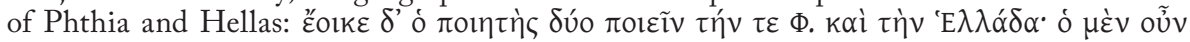

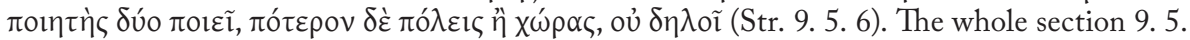
5-8 witnesses the difficult identification between the Homeric text and the real geographical context contemporary to the historian (Fowler 2011). According to him, Phthia was situated at the south of Mount Othrys, Hellas to its north, 60 stadia from Pharsalus; nothwithstanding this, some modern commentators site Pharsalus to the south of the Spercheios valley, next to the reign of Asia Minor (Hainsworth ad Il. 9. 395; Hope Simpson-Lazenby 1970).

${ }^{59}$ For a synthetical introduction to the question see Walbank on Plb. 18. 20. 2-8; with detailed contributions Pritchett 1969 and Decourt 1990; Hammond 1988: 60-82, esp. 65, 67,71 .

${ }^{60} \mathrm{It}$ is interesting to point out that on the Trismegistos database (http://www.trismegistos. $\mathrm{org} / \mathrm{geo} /$ ) Thetideion is the old name of the actual site of Alkhani, at the southwest of 
who proposed the identification of the Thetideion (as the temple of Thetis) with the church of Agios Athanasios on the crest of a ridge between Dasolophos and Orman Magoula ${ }^{61}$. This suggestion has been accepted by many scholars ${ }^{62}$ and fits the ancient sources better than the other competing identifications ${ }^{63}$. The site is just across the Enipeus river from the suggested site of the Old Pharsalus ${ }^{64}$ : Thetideion was located on the northern side of the Enipeus' valley, next to the eastern border of Pharsalus ${ }^{65}$, while on the other side of the Enipeus there was the place called Palaipharsalos by Strabo ${ }^{66}$. Furthermore, this hypothesis matches also with the description of the battle of Cynoscephalae and with the same Euripidean text, since it fits the idea that the skené is in Thetideion in the region of Phthia.

To sum up, it could be said that Euripides chose to set his play in Thetideion and treated it as a place with a shrine dedicated to Thetis, and with at least a royal palace. This place was sparsely populated and, even if some ancient sources that witness its existence defined it a polis, there is not enough evidence that Thetideion was "as a substantial urban or political entity"67, i.e. to claim that Thetideion was a polis in a proper and classical sense.

\section{Bibliography}

Allan, W. (2000), The Andromache and Euripidean Tragedy. Oxford, New York. Aston, E. (2009), “Thetis and Cheiron in Thessaly", Kernos 22: 83-107.

Battezzato, L. (2016), "Euripides the Antiquarian”, in A. Rengakos, P. Kyriakou (eds.), Wisdom and Folly in Euripides. Berlin, 3-19.

Battezzato, L. (2018), Euripides, Hecuba, edited and commented by Luigi Battezzato. Cambridge.

Skotoussa (http://www.trismegistos.org/place/33593; for the map: http://www.geonames. org/252937/thetidio.html).

${ }^{61}$ Giannopoulos 1902: 427-428.

${ }^{62}$ Giannopoulos' identification is adopted in Stählin 1924: 141; RE s.v. Kynoskephalai (1924): 35; RE s.v. Thetideion (1936): 205-206; Béquignon (1932; 1960: 176, with photos); Pritchett 1969; Decourt 1990; Walbank on Plb. 18. 20. 2-8.

${ }_{63}$ The arguments against the other hypotheses are well advanced and summed up by Pritchett 1969: 116-118.

${ }^{64}$ Ivi: 116.

${ }^{65}$ Eur. Andr. 16; Decourt 1990: 205-208.

${ }^{66}$ Decourt 1990: 207-223.

${ }^{67}$ Fowler 2013: 446. 
Béquignon, Y. (1932), "Études thessaliennes. V. Recherches archéologiques dans la région de Pharsale", BCH 56: 89-191.

Béquignon, Y. (1960), "Études thessaliennes. X. Nouvelles observations sur le champ de bataille de Pharsale", BCH 84: 176-188.

Cropp, M. J. (2013, 2a ed.), Euripides, Electra, with Introduction, Translation and Commentary by M. Cropp. Oxford.

Decourt, J.-C. (1990), "La vallée de l'Énipeus en Thessalie. Études de topographie et de géographie antique", $B C H$, Supplément XXI. Paris.

Decourt, J.-C., Nielsen, T. H., Helly, B. (with the assistance of R. Bouchon, L. Darmezin, G. Lucas, I. Pernin) (2004), "Thessalia and Adjacent Regions", in Hansen, M. G., Nielsen, T. H. (coords.), An Inventory of Archaic and Classical Poleis. An Investigation Conducted by The Copenhagen Polis Centre for the Danish National Research Foundation. Oxford, 676-731.

Diggle, J. (1984), Euripidis Fabulae, edidit J. Diggle, Tomus I insunt Cyclops, Alcestis, Medea, Heraclidae, Hippolytus, Andromacha, Hecuba. Oxonii.

Dolcetti, P. (2004), Ferecide di Atene, Testimonianze e frammenti: introduzione, testo, traduzione e commento a cura di Paola Dolcetti. Alessandria.

Drachmann, A. B. (1997, 2ª ed.), Scholia Vetera in Pindari Carmina: Volumen III. Scholia in Nemeonicas et Isthmionicas, Recensuit A. B. Drachmann. Stuttgardiae et Lipsiae.

Dunn, F. (2000), "Euripidean Aetiologies”, CB 76: 3-27.

Figueira, T. (2008), “The Copenaghen Polis Centre: a Review Article of its Publications. Part 4", AWE 7: 306-334.

Figueira, T. (2009), "The Copenaghen Polis Centre: a Review Article of its Publications. Part 5", AWE 8: 262-278.

Fowler, R. L. (1998), "Genealogical Thinking”, Proceedings of the Cambridge Philological Society 44: 1-19.

Fowler, R. L. (2000), Early Greek Mythography. Volume 1: Texts. Oxford.

Fowler, R. L. (2011), “Thessaly”, in M. Finkelberg (ed.), The Homer Encyclopedia, vol. III. Malden, 870-871.

Fowler, R. L. (2013), Early Greek Mythography. Volume 2: Commentary. Oxford. Gantz, T. (1993), Early Greek Myth. Volume One. Baltimore.



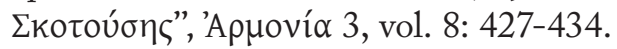

Griffin, J. (1980), Homer on Life and Death. New York.

Hainsworth, B. (1993), The Iliad: a Commentary, Volume III: books 9-12. Cambridge. 
Hall, J. M. (2002), Hellenicity. Between Ethnicity and Culture. Chicago, London. Hammond, N. G. L. (1988), "The Campaign and the Battle of Cynoscephale in 197 BC", JHS 108: 60-82.

Hansen, M. G. (2006), Polis. An Introduction to the Ancient Greek City-State. Oxford.

Hansen, M. G., Nielsen, T. H. (2000), “The Use of Word Polis in the Fragments of Some Historians", in P. Flensted-Jensen (ed.), Further Studies in the Ancient Greek Polis. Stuttgart, 141-150.

Heyne, C. G. (1783), Ad Apollodori Atheniensis Bibliothecam Notae, auctore Chr. G. Heyne. Goettingae.

Hope Simpson, R., Lazenby, F. (1970), The Catalogue of Ships in Homer's Iliad. New York.

Johansen, H. F., Whittle, E. W. (1980), Aeschylus, The Suppliants, edited by Holger Friis Johansen \& Edward W. Whittle, 3 voll. Copenaghen.

Jouan, F. (1966), Euripide et les légendes des chants cypriens. Des origines de la guerre de Troie à l'Iliade. Paris.

Kannicht, R. (ed.) (2004), Euripides, Tragicorum Graecorum Fragmenta, vol. 5. 1-2. Göttingen.

Kovacs, D. (1995), Euripides, Children of Heracles, Hippolytus, Andromache, Hecu$b a$, edited and translated by David Kovacs. Cambridge (MA).

Kovacs, D. (1998), Euripides, Suppliant Women, Electra, Heracles, edited and translated by David Kovacs. Cambridge (MA).

Kühner, R., Blass. F. W. (1890-1892), Ausführliche Grammatik der griechischen Sprache: Elementar- und Formenlehre. Hannover.

Kuntz, M. (1993), Narrative Setting and Dramatic Poetry. Leiden, New York, Köln. Larson, J. (2007), “A Land Full of Gods: Nature Deities in Greek Religion”, in D. Ogden (ed.), A Companion to Greek Religion. Malden, 56-70.

Latacz, J. (2003), Homers Ilias Gesamtkommentar, herausgegeben von Joachim Latacz, Band II, zweiter Gesang (B), Faszikel 2. München, Leipzig.

Lefkowitz, M. (2016), Euripides and The Gods. New York.

Liapis, V. (2012), A Commentary on the Rhesus Attributed to Euripides. New York.

Lloyd, C. (2006), “The Polis in Medea: Urban Attitudes and Euripides' Characterization in "Medea" 214-224", The Classical World 99, n 2: 115-130.

Lloyd, M. (2005, 2a ed.), Euripides, Andromache, with introduction, translation, and commentary by Michael Lloyd. Warminster.

Louden, B. (2005), “The Gods in Epic, or the Divine Economy”, in J. M. Foley (ed.), A Companion to Ancient Epic. Malden, 90-104. 
Mackie, C. J. (2011), "Phthia”, in M. Finkelberg (ed.), The Homer Encyclopedia, vol. II. Malden, 667.

Matthiae, A. (1829), Euripidis Tragoediae et Fragmenta, Tomus Nonus. Lipsiae.

Merkelbach, R. (1971), “KOPO乏”, ZPE 8: 80.

Mili, M. (2015), Religion in Ancient Thessaly. Oxford.

Mirto, S. (2012), "La figura di Teti e la crisi del gamos eroico nell'Andromaca di Euripide", Materiali e Discussioni 69, vol. 2: 45-70.

Montanari, F. (1988), I frammenti dei grammatici Agathokles, Hellanikos, Ptolemaios Epithetes. In appendice i grammatici Theophilos, Anaxagoras, Xenon. Berlin, New York.

Naiden, F. S. (2006), Ancient Supplication. New York.

Pritchett, W. K. (1969), Studies in Ancient Greek Topography. Battlefields. Berkeley, Los Angeles.

Rehm, R. (1988), “The Staging of Suppliant Plays”, GRBS 29: 263-307.

Rehm, R. (2002), The Play of Space: Spatial Transformation in Greek Tragedy. Princeton, Oxford.

Schwartz, E. (1891), Scholia in Euripidem, collegit recensit edidit Eduardus Schwartz, Volumen II: Scholia in Hyppolitum, Medeam, Alcestin, Andromacham, Rhesum, Troades. Berolini.

Scodel, R. (2012), Euripides, Andromache, Hecuba, Trojan Women. Translated by Diane Arnson Svarlien. Introduction and Notes by Ruth Scodel. Indianapolis.

Scullion, S. (1999-2000), "Tradition and Invention in Euripidean Aitiology", ICS 24/25: 217-233.

Seaford, R. (2009), "Aitiologies of Cult in Euripides: A Response to Scott Scullion", in J. R. C. Cousland and J. R. Hume (eds.), The Play of Texts. Essays in Honour of Martin Cropp, Leiden, Boston, 221-234.

Slatkin, L. (1991), The power of Thetis: Allusion and Interpretation in the Iliad. Berkeley, Los Angeles, Oxford.

Smyth, H. W. (1920), A Greek Grammar for Colleges. New York, Boston, Cincinnati, Atlanta, Chicago.

Sourvinou-Inwood, C. (2003), Tragedy and Athenian Religion. Lanham, MD, New York.

Stählin, F. (1924), Das Hellenische Thessalien. Stuttgart.

Stevens, P. T. (1971), Euripides, Andromache, edited with introduction and commentary by P. T. Stevens. Oxford.

Stockert, W. (1992), Euripides Iphigenie in Aulis, Band 1: Einleitung und Text; Band 2: Detailkommentar. Wien. 
Thomas, R. (1989), Oral Tradition and Written Record in Classical Athens. Cambridge.

Vidal-Naquet, P. (1968), "Le chasseur noir et l'origine de l'éphébie athénienne”, Annales. Économies, sociétés, civilisations 23: 947-964.

Vissner, E. (1997), Homers Katalog der Schiffe. Stuttgart und Leipzig.

Walbank, F. W. (1967), A Historical Commentary on Polybius, by F. W. Walbank, Volume II. Commentary on books VII-XVIII. Oxford.

Wilamowitz-Moellendorff, U. (1969), Euripides, Herakles, 3 voll. Darmstadt.

Willink, C. W. (1986), Euripides, Orestes, with introduction and commentary by C. W. Willink. Oxford. 